\title{
TWIN BALANCE SHEET PROBLEM - IS PUBLIC SECTOR ASSET REHABILITATION AGENCY A PANACEA?
}

\author{
*Inchara P. M Gowda ～**Dr. K. R. Manjunatha
}

\begin{abstract}
:
Employment/investment of borrowed capital by the corporate on assets or in projects which fail to generate an adequate rate of return results in the assets (i.e., investment) not performing well in the balance sheet of corporate borrowers. This is one Balance Sheet problem. This failure results in the non-payment of interest on the borrowed capital to the lending banks. Hence, the banks' loans and advances (an item of banks' balance sheets) fail to receive the interest income from their borrowercorporate - again leading to non-performing loans (NPLs or NPAs). This is another Balance Sheet problem. These problems are categorized as twin balance sheet (TBS) problems. To address and resolve this TBS problem, the Government of India and the Reserve Bank of India have formulated/ enacted a few schemes/Acts such as The Securitization and Reconstruction of Financial Assets and Enforcement of Security Interest Act, 2002 (SARFAESIAct, 2002); Debts Recovery Tribunals (DRTs) and Debts Recovery Appellate Tribunals (DRATs); Lok Adalats; Joint Lenders' Forum (JLF); Corporate Debt Restructuring (CDR, 2001); Strategic Debt Restructuring (SDR, 2015); Flexible refinancing under $5 / 25$ Scheme, S4A, etc. However, these Schemes have not been able to resolve the TBS problem. Hence, the GoI, in the Economic Survey, 2016-17, mooted the idea of setting up of a new central agency called, Public Sector Asset Rehabilitation Agency (PARA) to address the largest and the most difficult cases and to take politically tough decisions to reduce the debt of public sector which in turn enable the banks to reduce their NPAs. In this backdrop, this paper makes an attempt to present the magnitude of NPAs of $S C B S$, an overview of schemes formulated by the GoI/RBI to address NPA problem, nature of TBS and different facets of the proposed new agency, PARA.
\end{abstract}

Key Words: ARCs, CDR, DRTs, Gross and Net NPAs, JLF, PARA, S4A, SARFAESI, SDR, Stressed Assets, TBS Problem

\section{Introduction}

Indian Banking Industry is plagued with comparatively high rate of non-performing loans/assets (NPLs/NPAs)1. And the major contributor to this alarming rate of banks'
NPAs is their corporate borrowers. However, this NPA has multiple ill-effects on the banks, economy, etc. The banks use the deposits of the general public to lend to corporate - these corporate advances, in some cases, are not bringing the interest income to the banks and

\begin{tabular}{l|l|l|l} 
Inchara P. M Gowda & $\begin{array}{l}\text { II Author } \\
\text { Desearch Scholar, } \\
\text { R. R. Manjunatha } \\
\text { Institute of Management Studies, } \\
\text { Kuvempu University, } \\
\text { Jnana Sahyadri, Shankaraghatta }\end{array}$ \\
\hline
\end{tabular}


the principal loan amounts are not repaid as per payment schedule. This results in (i) decline in the amount of interest income of banks, (ii) decline in the amount of banks' profit, (iii) locking up of banks' fund with the borrowingcompanies leading to strain on the banks' ability to recycle the credit and depriving others an opportunity to borrow from the banks, (iv) higher rates of Provisioning for the NPAs which in turn results in lower profits and profitability of banks, etc. The increasing NPLs, on the one hand, reduces the interest income of banks which is one of their major sources of income and require higher Provisioning on the other - both affecting their profitability adversely.

\section{SCBs - A Brief Review of NPAs}

The gross advances made by the Scheduled Commercial Banks (SCBs) to the corporate borrowers and others, till the end of March 2013, amounts to $59,882.8$ billion. And the net advances amount to 58,797 billion. Of this loans and advances, and the interest amounts due on these loans and advances, 1,931.94 billion is categorized as NPAs as per the guidelines of the Reserve Bank of India (RBI). This NPA works out to 3.2 per cent of gross advances made by the banks. Of course, the SCBs have done a commendable job to lower the rate of NPAs (to gross advances) as evident from the following (Table -1$)$.

Table - 1: Gross NPAs as a Perc entage of Gross Advances

\begin{tabular}{|c|c|c|c|}
\hline $\begin{array}{c}\text { Year (end- } \\
\text { March) }\end{array}$ & $\begin{array}{c}\text { Gross NPAs as a \%age } \\
\text { of Gross Advances }\end{array}$ & $\begin{array}{c}\text { Year (end- } \\
\text { March) }\end{array}$ & $\begin{array}{c}\text { Gross NPAs as a \%age } \\
\text { of Gross Advances }\end{array}$ \\
\hline $2001-02$ & 10.4 & $2007-08$ & 2.3 \\
$2002-03$ & 8.8 & $2008-09$ & 2.3 \\
$2003-04$ & 7.2 & $2009-10$ & 2.4 \\
$2004-05$ & 5.2 & $2010-11$ & 2.5 \\
$2005-06$ & 3.3 & $2011-12$ & 2.9 \\
$2006-07$ & 2.5 & $2012-13$ & 3.2 \\
\hline
\end{tabular}

Source: Compiled on the basis of the data accessed on 8 February 2017 from the website of RBI, https://rbi.org.in/scripts/SearchResults.aspx?search=Bank Groupwise NPAs

It is obvious from the above that the banks have succeeded in reducing their NPA rates continuously year after year up to the end of 2007-08 which is commendable. Thereafter, it is either constant (2008-09) or increasing on a continuous basis (from 2009-10) which is a matter of concern.

However, what is further worrying is that the gross NPAs of state-run banks are expected to increase from 9.6 percent as of March 2016 to 10.1 - 11 percent by March 2017. Continuously increasing NPAs (gross) necessitated the banks to make provisioning for these NPAs as per the guidelines of the apex bank. It is reported that the provisioning made by public sector banks (PSBs) for NPAs lead to a cumulative loss of 180 billion. Further, for the years 2012-13 to 2014-15, it is reported that the banks had to write off 1.14 lakh crores affecting their profitability adversely. As a result of provisioning, the net NPAs are much lower than the gross NPAs. For example, till the end of March 2013, the gross and net NPAs amounted to `1,931.94 billion and `986 billion 
respectively. That means, the SCBs have made provisioning, until the end of March 2013, to the tune of ` 945.94 billion. However, as in the case of Gross NPAs to Gross Advances Ratio, the Ratio of Net NPAs to Net Advances registered a continuous decline initially, thereafter, it remained constant for a few years and started increasing in the later years as evident from the following table $($ Table - 2).

Table - 2: Net NPAs as a Percentage of Net Advances

\begin{tabular}{|c|c|c|c|}
\hline $\begin{array}{c}\text { Year (end- } \\
\text { March) }\end{array}$ & $\begin{array}{c}\text { Net NPAs as a \%age } \\
\text { of Net Advances }\end{array}$ & $\begin{array}{c}\text { Year (end- } \\
\text { March) }\end{array}$ & $\begin{array}{c}\text { Net NPAs as a \%age } \\
\text { of Net Advances }\end{array}$ \\
\hline $2001-02$ & 5.5 & $2007-08$ & 1.0 \\
$2002-03$ & 4.0 & $2008-09$ & 1.1 \\
$2003-04$ & 2.8 & $2009-10$ & 1.1 \\
$2004-05$ & 2.0 & $2010-11$ & 1.1 \\
$2005-06$ & 1.2 & $2011-12$ & 1.3 \\
$2006-07$ & 1.0 & $2012-13$ & 1.7 \\
\hline
\end{tabular}

Source: Compiled on the basis of the data accessed on 8 February 2017 from the website of RBI, https://rbi.org.in/scripts/SearchResults.aspx?search=Bank Groupwise NPAs

As can be seen from the above, the Net NPA Ratio has declined from 5.5 percent for 2001-02 to 1 percent by 2006-07 and it remained constant even during 2007-08. However, it increased to 1.1 percent in 2008-09 and to 1.3 percent in 2011-12 and to 1.7 percent in 2012-13 which should be a matter of concern. This is because of the reason that even after making necessary provisioning, as per the prudential norms of the RBI, the net NPA is positive. This indicates the inadequacy in the Provisioning made toward NPAs. It may be noted here that a part of decline in the net NPAs can be attributed to continuously increasing Provisioning made by the SCBs.

Out of four major groups of SCBs viz., Public Sector Banks (PSBs), Old Private Sector Banks, New Private Sector Banks and Foreign Banks in India, the performance of PSBs, from the point of view of management of NPAs, is not satisfactory followed by Foreign Banks in India, Old Private Sector Banks and New Private Sector Banks. A few details pertaining to the Gross and Net NPA Ratios (i.e., Ratio of Gross NPAs to Gross Advances, and the Ratio of Net NPAs to Net Advances) for the year ended 31 March 2013 substantiate this inference (Table - 3).

Table - 3: SCBs - Bank Group-wise Gross and Net NPA Ratios as at 31 March 2013

\begin{tabular}{|l|c|c|}
\hline \multicolumn{1}{|c|}{ Bank Group } & $\begin{array}{c}\text { Gross NPAs as a \%age } \\
\text { of Gross Advances }\end{array}$ & $\begin{array}{c}\text { Net NPAs as a \%age } \\
\text { of Net Advances }\end{array}$ \\
\hline Public Sector Banks & 3.6 & 2.0 \\
Foreign Banks in India & 3.0 & 1.0 \\
Old Private Sector Banks & 1.9 & 0.7 \\
New Private Sector Banks & 1.8 & 0.4 \\
\cline { 2 - 3 } Average for all SCBs & 3.2 & 1.7 \\
\hline
\end{tabular}

Source: Compiled on the basis of the data accessed on 8 February 2017 from the website of RBI, https://rbi.org.in/scripts/SearchResults.aspx?search=Bank Groupwise NPAs 
It may be noted from the above table that the NPA ratios of PSBs are higher than the averages for all SCBs. And these ratios are lower in the case of New Private Sector Banks and Old Private Sector Banks. However, what is surprising is that the performance of Foreign Banks in India is poorer than the Private Sector Banks (both Old and New) but slightly higher than that of PSBs.

However, what is apparent are the continuously increasing amounts of gross and net NPAs owing to perennially increasing stressed assets. "These NPAs are, however, inevitable in the loan portfolio and they are not a one-time phenomenon. The inordinate delay in the recovery of loans builds up NPAs causing the increase in the cost of financial intermediation as the banks have to resort to additional borrowings at comparatively higher costs" (Inchara P. M Gowda, September 2016).

\section{Literature Review}

A large number of studies have been undertaken and completed in the past by both the individual and institutional researchers on different dimensions of NPAs. These studies comprise the global level, national level, and regional level studies, and also bank specific studies. And different approaches have been employed by the researchers to examine the effectiveness with which the banks are managing their stressed assets and the NPAs. In this background, an attempt is made to present a brief review of a few important works relevant to the present study.

A number of schemes have been designed and implemented by the governments for the promotion/development of small-scale industries (SSIs). Still, many a number of units are facing the financial problem. It may be noted here that the commercial banks are also lending to these SSIs. In this backdrop, Parameshwara (2015) selected 466 SSIs in the districts of Dakshina Kannada and Udupi (Karnataka) for evaluating the recovery management of loans to SSIs by commercial banks. It is found that the banks which had advanced loans to these units are now facing problem in the recovery of their loans. He, therefore, suggested the banks to follow aggressive credit appraisal and to strengthen their debt recovery mechanism.

Banks are the principal source of capital for small and medium enterprises (SMEs). And the NPAs of lending banks, therefore, reflect the success of these organizations. Using a simple co-integration test, it is found that, after the 1990s, larger NPAs are associated with larger advances and vice-versa (Soumitra K. Mallick, Amitava Sarkar, Kalyan K Roy, Tamal Duttachaudhuri \& Anjan Chakrabarti, April 2010).

After evaluating the impact of real and financial fragility on default losses of Italian banks, Chiara Pederzoli, Costanza Torricelli \& Simona Castellani (November 2010) observed that "though the economic environment has the expected effect on the loan losses of banks independent of the size of the firms, the impact of indebtedness of firms depends upon the size of the firms - more for small firms. Further, for small firms, the impact of financial fragility is increased by adverse economic environment while the same effect for medium- and largefirms does not hold".

Asper Basel - III, increase in default risk requires the increase in equity of commercial banks which is a tough task for the mediumand small-sized banks in Katowice in short time. Joanna Cichorska (2014), therefore, observes that the requirement of Basel - III has 
forced the banks to limit their active operations i.e., reducing lending.

Both Serbia and Montenegro operated, until 1999, under a common monetary regime and thereafter, followed two different monetary systems - monetary independence in Serbia and unilateral euroisation in Montenegro. Using bank-specific and country-specific variables, Alexandre Sokic (September 2015) finds that a bank operating at given conditions in terms of ownership, market and other specific characteristics presents significantly higher cost efficiency if it operates in Montenegro rather than in Serbia.

An analysis of the impact of corruption on both the banking industry and the economic growth with the help of macroeconomic data from 76 countries over a period of 2002-04 shows that the "corruption has significantly aggravated the problems with bad loans in the banking sector. It is also found that the corruption distorts the allocation of bank funds from normal projects to bad projects which deteriorate the quality of private investments leading to decrease in the economic growth" (Junghee Park, September 2012).

Evaluation of the efficiency of Chinese commercial banks revealed that the efficiency of Chinese banks improved during 2003-14. Improvement is also observed in resolving the problem of high rate of NPAs. Though the trends in efficiency remain the same, scale efficiency improved substantially until 2008 and thereafter, the improvement has been moderate. In this background, Mingxuan Tuo (April 2016) suggested the Chinese banks to continue to improve their management capacity and innovation, and these attempts are expected to improve the efficiency of banks further supporting the development of Chinese economy.
On the lines of the above, many more studies have been undertaken and completed in the past by the researchers. However, all these studies reveal that the performance of lending banks depends, to a greater extent, on the successful operation of borrowing corporate. The review also shows that the NPAs or NPLs have a direct adverse impact on the financial performance of the lending banks.

\section{Measures of the GoI and other Authorities}

Realizing the adverse implications of NPAs, both the GoI and the RBI have enacted/ formulated a few Acts/schemes to resolve the problem of banks' NPAs. These are in addition to the measures taken by the lenders at the bank level to address this issue. A few important schemes/Acts formulated/enacted by the $\mathrm{RBI} /$ Government are presented below with a very brief analysis. It may be noted here that the very purpose of these schemes/Acts is to strengthen the hands of lending banks to recover the amounts due from the borrowerunits and to clean their balance sheets. Further, they also intend to reduce the debt burden of corporate borrowers.

(1) SARFAESI Act, 2002 (The Securitisation and Reconstruction of Financial Assets and Enforcement of Security Interest Act, 2002): The GoI enacted this Act with the objective of speeding up the recovery process. This Act empowers the lending banks/financial institutions to recover their NPAs without the intervention of the Courts. For the purpose of loan recovery, it provides three alternative mechanisms as presented below.

(a) Securitization which empowers the secured creditors to take possession of the securities offered by the borrowers if they fail to adhere to the payment schedule and 
to sell such securities for recovering their loan.

(b) Setting up of Securitization/Reconstruction Companies (SCs/RCs) to acquire the NPAs from the banks thereby cleaning the banks' balance sheets and enabling them to concentrate on their primary banking business operations.

(c) Enforcement of Security - The Act empowers the $\mathrm{SCs} / \mathrm{RCs}$ to take possession of the secured assets of borrowers including the right to transfer and realize the secured assets.

(2) DRTs and DRATs: With the primary objective of providing for expeditious adjudication and recovery of debts due to banking and financial institutions (with outstanding amount of ' 10 lakhs and above), the GoI established 33 Debts Recovery Tribunals (DRTs) and five Debts Recovery Appellate Tribunals under the Provisions of Recovery of Debts Due to Banks and Financial Institutions Act, 1993 (RDDBFI).

(3) Lok Adalats: This is an alternative disputes resolution (ADR) mechanism which provides for expeditious, inexpensive and mutually acceptable way of settlement of disputes between the lending banks and borrowing parties. Hence, the banks and financial institutions are advised to explore this methodology to the maximum extent to recover the amounts due in NPA accounts.

(4) RBI's Schemes: With the objective of enabling the banks to resolve their problem of stressed assets, the apex bank of the country has designed and introduced a few schemes. These include the following, among others.

(a) Joint Lenders' Forum (JLF) to empower the smaller lender-banks,

(b) Corporate Debt Restructuring (CDR, 2001) enabling the banks to help the ailing corporates with additional funds based on majority decision,

(c) Strategic Debt Restructuring (SDR, 2015) enabling the lender-banks to take control of management and to convert their outstanding loans into majority equity stake,

(d) Flexible refinancing under 5/25 Scheme, etc.

(e) The apex bank has also come out, in June 2016, with a new scheme called, Scheme for Sustainable Structuring of Stressed Assets as another option for the banks to deal with the stressed assets arising out of their corporate lending.

\section{Objectives of the Study}

The above attempts/mechanisms, in the opinion of the GoI, have not been able to produce the desired result i.e., in resolving the mounting NPAs of SCBs and also that of corporates for one reason or the other. Of course, this is a fact. For example,

(1) The Asset Reconstruction Companies (ARCs) have been able to solve only a small portion of the problem - buying only 5 per cent of NPAs at their book value during 2014-16 and landed themselves in a problem as it was difficult to recover from the debtors.

(2) Though two dozen enterprises have entered into negotiations under SDR, only 
two cases have been concluded by the end of December 2016.

(3) So far, only one small case has successfully been solved under S4A.

Coordination problems (as large debtors may have many creditors with diverse interests), inability of lenders to find a suitable buyer, delay in the process of converting debt into equity, non-cooperation of borrowers, failure of ARCs to resolve bad debts, etc., are some of the reasons attributed for not being able to resolve the problem of NPAs. This has prompted Sri Arun Jaitley, Finance Minister, GoI, to propose a new mechanism called, Public Sector Asset Rehabilitation Agency (PARA) in his presentation of Economic Survey, 2016-17 in the Parliament on 31 January 2017. This paper makes an attempt to analyze the salient features of this new mechanism such as twin balance sheet (TBS) problem, the methodology under PARA, evaluation of PARA, etc., based on the details provided in the Economic Survey.

\section{TBS Problem}

Both the Economic Surveys of 2015-16 and 2016-17 have recognized an important challenge confronting the economy viz., the twin balance sheet (TBS) problem. The twin balance sheets referred here are that of SCBs and corporate borrowers.

It may be noted here that the performance of lending banks is directly influenced by that of corporate borrowers. The corporate units are required to exercise paramount care while assessing their financial needs (i.e., to determine the minimum fund required), mobilizing fund (i.e., to mobilize only from the economical sources and in types), employing fund (i.e., to employ the borrowed fund judiciously and optimally), etc., so that the investments made by the borrower earn higher return than the cost of borrowed capital. If this is done, then the borrower entities find no difficulty in the timely payment of interest and also in the repayment of principal loan amount. Unfortunately, in a few cases, this is not happening. For instance, during the boom periods, the corporate enterprises borrowed huge money from the banks and invested the same in infrastructure and capital-intensive industries such as steel, power, etc. They borrowed huge amounts from banks ranging from ' 100 to ' 1,000 crores and invested in projects with longer gestation period. Owing to slump in the business of these sectors in the recent years, the borrowing units' profits have declined substantially and the profit has become the casualty/ victim of the business slump. Consequently, the corporate borrowers are unable to keep up their payment schedule. As a result, their debts start rising at an alarming rate forcing them to cut back investments. This resulted in the creation of financial burden not only on the borrower-units but also on lender-bankers and the economy as a whole. In other words, the arrears on the projects are so high that the companies find it very difficult to repay the debts. Such investments are categorized as NPAs in the balance sheets of the corporate units. Similarly, the loans advanced by the banking institutions for these projects are considered as NPAs/NPLs in their balance sheets. TBS is, therefore, a situation where the corporate enterprises overexpand their activities during a boom period leading to over leveraging funds which, now, they are unable to repay. This results in default on their debts which in turn impair the quality of loans provided by the banks - a few corporates are heavily leveraged reflecting as 
stressed assets on the balance sheets of banks. The nature of TBS problem of stressed corporate and banks' balance sheets is presented below (Figure - 4).

\section{Figure - 4: Twin Balance Sheet Problem}

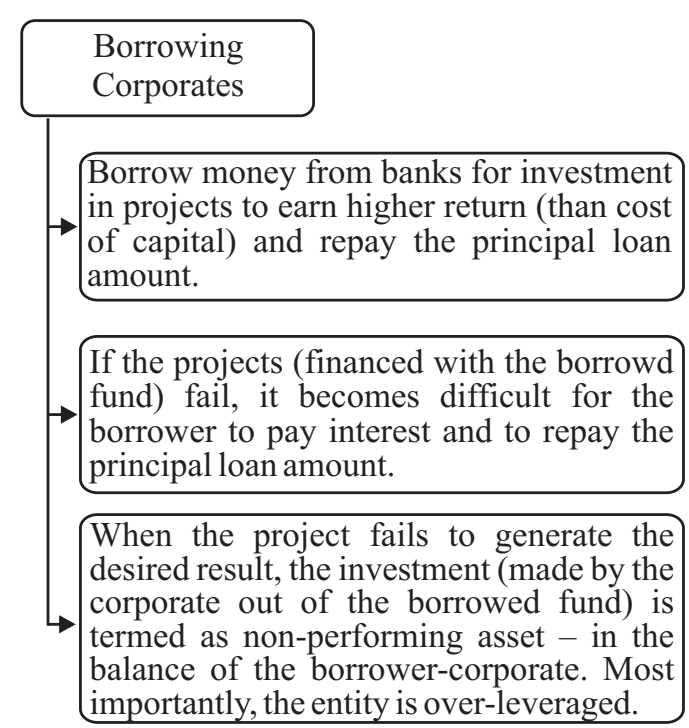

According to the Economic Survey, 2016-17, the gross NPAs of PSBs climbed $12 \%$ over gross advances by the end of September 2016. This is higher than any other major emerging market except Russia. This is because of the reason that the cash flows in the large stressed companies have deteriorated to the level which requires debt reductions by more than 50 percent to bring them back to a viable situation. Further, based on the relevant data for the period ending September 2016 for the top 100 stressed debtors, it is estimated that,

(1) about 33 need debt reductions of less than 50 percent,

(2) another 10 need reductions of $51-75$ percent, and

(3) at least 57 need reduction of 75 percent or more.

However, the squeeze of banks resulted in their slow credit growth to some of the key sectors including MSMEs. This is a vicious circle affecting the whole economy if failed to
Lending Banks

Provide loans and advances to corporate

$\rightarrow$ houses for a specified interest and on specific

terms and conditions.

If the borrower fails to pay the interest and to repay the principal loan amount, it lowers the interest income of banks leading to reduced net interest spread, Return on Advances, etc. When a large portion of their loan portfolios is impaired, it becomes very difficult for them to meet their recurring expenses including interest cost and to recycle the credit.

When the borrower fails to make the payments (interest and principal) in accordance with the loan terms, the loan (under consideration) is said to be non-performing loan or asset - in the balance sheet of lending bank.

manage it properly and timely. And therefore, the country is facing with the TBS problem of over-leveraged companies and bad-loanencumbered banks.

\section{Public Sector Asset Rehabilitation Agency (PARA)}

In the light of mounting NPAs of both lenders and borrowers, inability of ARCs to produce the desired result in the form of resolving the problem of NPAs, etc., and with the objective of working out the largest and most complex cases loan resolution, the GoI in its Economic Survey, 2016-17, mooted the idea of creating another agency called, Public Sector Asset Rehabilitation Agency (PARA). The agency will be required to handle the largest and the most difficult cases, and to take politically tough decisions to reduce the debt of public sector. This agency is expected to take care of both the borrowing corporates and the lending banking/ financial institutions. In this regard, four important aspects are to be noted. 
(1) The new agency will be required to take up cases of large but difficult cases. This assumes importance as a very few large corporates have borrowed huge sums from the banking/financial institutions, and in some cases, these large borrowers have not been able to keep up their payment schedule resulting in NPAs for themselves and also for the lending banks. If these cases are resolved, then it will be a big relief to both the borrowers and lenders. Therefore, the Economic Survey noted that though the large cases are difficult to resolve, they providean opportunity to tackle fewer cases to resolve the TBS problem.

(2) The new proposed agency, PARA, is not a substitute for any or all of the existing arrangements for resolving the problem of TBS. Rather, it is an additional arrangement (i.e., in addition to ARCs, etc) aiming at resolving the problem of TBS resolving NPAs, debt reduction, etc.

(3) The third important aspect is the political willingness to recognize the gravity of the problem and to deal with the consequences of loan write-offs (e.g.,Kingfisher Airlines bailout - stand of political parties when they are ruling parties and when they are in opposition). This requires the readiness to confront the losses already suffered by the banks and to accept the political imports of dealing with the problem. Therefore, there is a need for staffing the agency with independent, competent, qualified and professionals. This is necessary to follow the commercial principles instead of political considerations while addressing TBS problem.

(4) As far as the pricing of assets (which the agency will take over) is concerned, the
Economic Survey makes it very clear that it should be on market price. This is necessary because, if the loans made by the banks are transferred to PARA at inflated prices, it results in the banks transferring their losses to the PARA. However, the experience of ARCs shows that the determination of market price is not an easy task. And the Economic Survey is silent on the modalities of determining the market price. However, what is apparent is that restoring the financial health of public sector undertakings (PSUs) requires large writedowns. Further, the Survey noted that this situation is causing the increase in the costs for the government as bad debts of PSBs continue to climb, hindering credit, investment, and growth.

PARA is a 'bad bank' type structure aiming at resolving the NPAs problem. A 'bad bank' is a bank set up for the purpose of buying the bad loans (with a substantial portion of it being NPAs) of a bank at market price. In other words, it is a government-driven ARC where the lending banking/financial institutions can park their stressed assets. By selling its bad loan to bad bank, the lending bank clears its balance sheet of toxic assets i.e., the financial assets whose value has fallen substantially which cannot be sold at a price satisfactory to the lending bank. As a result, though this helps in relieving the individual (lending) banks from the pressure of stressed debt, it necessitates 'write-downs' in the books of the lending banks.

It may be noted here that the 'bad bank' concept is not a new concept. For example, when IDBI Ltd., was converted into a bank in 2004, the government set up a Stressed Asset Stabilisation Fund (SASF) to hive off its stressed and bad assets worth 9,000 crores. 
This was done to help the bank focus on its core business and assign the recovery task to a separate division. And this SASF recovered about `4,000 crores by the end of March 2014, said a report of the Comptroller and Auditor General of India. Even in a few other countries, this system (i.e., bad bank type structures) has been experimented - Troubled Asset Relief Program, TARP or the Emergency Economic Stabilization Act, 2008 (US); UK Asset Resolution (UK); National Asset Management Agency (Ireland), SAREB (Spain), etc.

PARA is expected to eliminate most of the obstacles currently plaguing loan resolution process. The new agency is expected to solve the coordination problem as the debts would be centralized in one agency. It is proposed to set up the new agency with proper incentives with an explicit mandate to maximize recoveries within a defined time period.This is expected to separate the loan resolution process from the banks so that they continue to concentrate on their core banking business.

As far as the funding of PARA is concerned, the Economic Survey identifies three alternative avenues - (i) issue of government securities, (ii) recourse to capital markets, and(iii) through the apex bank. As far as the third option is concerned, the Government is of the opinion that the apex bank of the country is one of the highly capitalized central banks in the world and this excess capital (including that created by the demonetization) is a balance sheet or wealth gain but not an income gain. Therefore, the uses to which this is put should be of a balance sheet nature - Economic Survey states. The government, therefore, feels that a part of this excess capital (about 4 lakh crores) can be redeployed to fund infusion in PSBs and for setting up of PARA. Besides, this can also be utilized for extinguishing debt.
However, it is feared that this may erode the resources of the apex bank.

Diversion of funds by the borrowing firms (for a purpose other than for which it was borrowed), employment of borrowed funds in non-revenue generating activities, unexpected changes in the economic environment in the post-financial crisis period, etc., have contributed to strain the resources of borrowing entities resulting in debt repayment problems. This requires sizeable write-downs to restore the financial health of PSUs. Further, many a number of these PSUs may have multiple creditors with different interest causing severe co-ordination problems. Therefore, it is difficult, both politically and financially, to provide them sizeable debt reductions and/or take them over and sell. All these results in the increase in the deterioration in the asset quality of lending banks hindering credit, investment, growth, etc. Besides, the (private run) ARCs have not been able to resolve the growing problem of bad debts. All these facts bring the point to the fore that there is a need for a professionally-run government-backed central agency to overcome the political issues and coordination problem.

PARA is expected to purchase the specified loans from banks granted to large, overindebted infrastructure and steel firms, and then work them out either by converting these loans/ debts into equity and selling the stakes through auctions and/or by providing debt reduction. Of course, the specific methodology to be employed by the PARA depends upon the professional assessments of the valuemaximizing strategy.

This centralized approach, it is hoped, is more effective than other mechanisms tried till now by the Indian authorities. This mechanism has successfully been tried in different countries including East Asian countries in the 1990s and 
these countries have been able to resolve their NPAs problem within two years. On the other hand, India has been trying with other mechanisms for the last eight years without much success. Hence, this professionally run government backed agency, PARA, is expected to overcome the difficulties in the path of resolving TBS problem and to resolve the NPAs/TBS problem.

\section{PARA - A Few Observations}

However, there are apprehensions about the success of the new agency, PARA. This is because of the reason that there are, at present, more than a dozen schemes/mechanisms/Acts, etc., to address the problem of NPAs/TBS. And the government/RBI designed these schemes with the full confidence that they will be able to address the issue effectively. But now, the government says that they have not been able to produce the desired result. This only shows the lack of seriousness in implementing the schemes. In the light of the experience with these mechanisms, there is a doubt about the success of even the new avatar, PARA. There is, therefore, a need for equipping the new agency, PARA, with necessary facilities including finance and professionals to resolve the problem of TBS. It may be noted here that mere setting up of a new mechanism does not ensure the result unless it is equipped with necessary facilities and power as otherwise, it adds only to the cost of the government.

Dr. Raghuram Rajan, the then Governor of RBI, had opposed (April 2016) the concept of 'bad bank' on the ground that the lending banks should be allowed and empowered to recover the dues. Further, he believed that as much of the assets backing the banks' loans are viable or can be made viable, it makes sense for the banks themselves to recover their loan amounts. Though the concept of 'bad bank' has not failed in other countries, it was not done fast enough - said Dr. Raghuram Rajan.

Another contentious issue with the new agency (as with ARCs) is the pricing of bad loans. Of course, outlines of PARA state that it should be at a market price which is very difficult to determine. It may be noted here that any overor under-pricing results in the failure of the agreement between the lending banks (which sell their bad loans to PARA) and the PARA (which buys the bad loans from lending banks). This is because of the reason that any over- or under-pricing results in loss to one party and gain to another party e.g., if it is over-priced, it is profitable to lending banks at the cost of PARA and vice-versa.

Political interference in India is omnipresent and banking/financial institutions are not excluded. The interference can be found in all stages damaging the financial soundness of banking system without taking any responsibility which is very dangerous. There is, therefore, a need for addressing this issue to ensure that the agency functions objectively and in the overall interest of the economy.

A major contributor to the problem of TBS is the changes in the macro-economic environmental factors (including the global economic environment) on which neither the lending banks nor the borrowing corporates have any control. It is the responsibility of the government to ensure the conducive economic environment for the banks and corporate to function properly. This is necessary as otherwise impaired loans of banks force them to scale back their credit on the one hand, and the stressed companies to cut their investment on the other - both are undesirable from the point of view of overall economic growth and development. 


\section{Conclusion}

The success of any scheme depends upon how effectively the scheme is implemented. About a dozen schemes designed and implemented by the authorities to resolve the problem of TBS have failed to produce the desired result owing to the lack of effective implementation. Of course, there are many reasons for this. However, one should learn from the past mistakes and try to improve the performance. Stressed assets and NPAs of banking and financial institutions, and that of the corporate borrower should be addressed with all seriousness and without political interference. This TBS problem is like a virus and if not injected the right medicine at the initial stage, it spreads to the entire economy and destroys it. It is, therefore, the right time for the government and other parties concerned to implement the provisions of PARA after equipping it with honest and efficient professionals and with necessary finance and powers to resolve the TBS problem.

\section{Notes}

(1) When a borrower fails to make the scheduled payments of interest and/or principal for a period of 90 days, the account is classified as non-performing loan/asset (NPL/NPA) requiring Provisioning as per the Prudential Norms of the Reserve Bank of India, RBI.

(2) Gross Advances represent the total amount of loans advanced by the banks. And Net Advances denote the difference between the gross advances and the repayments of principal i.e., Net Advances $=$ (Gross Advances - Repayments of Principal).

(3) Net NPAs $=($ Gross NPAs - Provisioning made for NPAs)

(4) "Stressed assets comprise (i) NPAs, (ii) restructured loans, and (iii) written-off assets. The restructured loans epitomize the loans which have got an extended repayment period, conversion of a part of the loan into equity, provision of additional financing, reduction in the interest rate or a combination of these measures. Consequently, after it restructures, a bad loan or NPL gets transformed into a new loan. And writing off of NPAs is a regular exercise carried out by the banks to clean up their balance sheets. However, a substantial portion of this write-off is, as clarified by the apex bank, technical in nature. In Technically Written Off accounts, though the loans are written off from the books at the Head Office, the banks do not give up their right to recovery. These write-offs are usually made against accumulated provisions already made for such loans. And if these written-off loans are recovered, the provisions already made (for these loans) flow back to the P\&L Accounts of banks" (Inchara P. M Gowda, December 2016).

(5) Subsequent to the amendment to the Government of India (Allocation of Business) Rules, 1961, the erstwhile Ministry of Agro and Rural Industries, and the Ministry of Small Scale Industries are merged to form the Ministry of Micro, Small and Medium Enterprises.

(6) i. e. when liberalization was introduced by the GoI by opening up a significant part of public sector for private players allowing private banks to do the banking business.

(7) Over-leveraged company is one which has a high portion of its capital in the form of debt resulting in its inability to service the debt (i.e., interest on debt capital) if it fails to conduct its business properly and profitably. 
(8) It may be noted here that the banks are finding it very difficult to make provisioning for their bad loans owing to low levels of capitalization. Therefore, the government has committed to infusing 70,000 crores into PSBs over a period of four years. However, the Rating agencies such as Investment Information and Credit Rating Agency of India Ltd (ICRA) estimates the required capital amount in the range of "1.5-1.8 lakh crores.

\section{References}

Alexandre Sokic. (September 2015). COST efficiency of the banking industry and unilateral euroisation: A stochastic frontier approach in Serbia and Montenegro. Economic Systems. 39 ( 3 ) : pp. 541-51.

Chiara Pederzoli, Costanza Torricelli \& Simona Castellani. (November 2010). THE interaction of financial fragility and the business cycle in determining banks' loan losses: An investigation of the Italian case. Economic Notes. 39(3): pp. 129-46.

Department of Economic Affairs. (January 2017). Economic survey 2016-17. Ministry of Finance. Government of India. pp. 82-104.

Inchara P. M Gowda. (September 2016). DEBT recovery bill. Money Wise. 4(9): $p$. 30 .
(December 2016).

S4A - A good move. Money Wise. 4(12): p. 31 .

Joanna Cichorska. ( ( 201014$)$. DELEVERAGING in the banking sector. Journal of Economics and Man a gement. Issue 16: pp. 5-15.

Junghee Park. (September 2012). CORRUPTION, soundness of the banking sector, and economic growth: A crosscountry study. Journal of International Money and Finance. 31(5): pp. 907-29.

Mingxuan Tuo. (April 2016). AN empirical analysis of Chinese commercial banks' efficiency and influencing factors. American Journal of Industrial and Business Management. pp. 455-66.

Parameshwara. (2015). RECOVERY management of commercial bank loans to small scale industries - A study in Dakshina Kannada and Udupi districts. Unpublished Thesis submitted to Mangalore University.

Soumitra K. Mallick, Amitava Sarkar, Kalyan K. Roy, Tamal Duttachaudhuri \& Anjan Chakrabarti. (April 2010). DYNAMICS of emerging India's banking sector assets: A simple model. Journal of Asset Management. 11(1): pp. 62-70. 